\title{
Association of the Black Rot Fungus Ciboria batschiana with the Chestnut Weevil Curculio propinquus in Chestnut Orchards in Central Italy
}

\author{
A.M. Vettraino, S. Speranza, B. Paparatti, C. Pucci and A. Vannini \\ Dipartimento Protezione delle Piante \\ Università degli Studi della Tuscia \\ via S. Camillo de Lellis snc \\ 01100 Viterbo \\ Italy
}

Keywords: $S$. pseudotuberosa, chestnut weevil

\begin{abstract}
The association of the black rot fungus Ciboria batschiana and the chestnut weevil Curculio propinquus was investigated. Insects from a single plantation located in a chestnut area in Viterbo, in the Lazio Region (Italy) were analysed for association with the fungus. Ciboria batschiana was detected in 2 out of 10 adults collected from the ground and 21 out of 22 adults from the trees. Only $33.3 \%$ of the larvae were found to be associated to the fungus. The ability of $C$. propinquus to carry the fungus was confirmed. Its role as a possible vector of this pathogen deserves further study.
\end{abstract}

\section{INTRODUCTION}

Ciboria batschiana (Zopf) Buchw. (syn Sclerotinia pseudotuberosa Rehm., anamorph Rhacodiella castaneae Pyr.) is the main cause of black rot of Castanea sativa nuts and it is the cause of serious economic losses during storage (Peyronel, 1920; Delatour and Morelet, 1979; Tian and Bertolini, 1997; Finch-Savage et al., 2003). Fruits colonised by the fungus rapidly become black and rotten and develop a dark grey mycelium. Infection is thought to occur on fruits when they fall to the ground before harvesting through ascospores issued from apothecia formed during the winter on infected fruits (Delatour and Morelet, 1979; Tian and Bertolini, 1997). However the presence of $C$. batschiana has been recently reported even in asymptomatic chestnut tissue, suggesting latency in the host (Vettraino et al., 2005). It is still unclear how branches, leaves and nuts could be infected by $C$. batschiana when still on the tree. The chestnut weevil Curculio propinquus (Desbr) is the key pest of the chestnut insects that feed and reproduce on chestnut (Paparatti et al., 2002; Speranza, 1999). The adults fly from the soil where they overwinter in late summer. The female lays eggs in the immature nuts and the newly emerged larvae feed in the nut until the end of the preimaginal instars. The mature larvae emerge from the ripe nuts and bury themselves in the ground and build an overwintering chamber. Symptoms of black rot in nuts are frequently observed in association with $C$. propinquus damage (Fig. 1).

Based on the knowledge of the role that some insects play as vectors of fungal diseases of woody trees (Müllera et al., 2002; Feci et al., 2003), this study aims to investtigate a possible association of $C$. batschiana with adults and larvae of $C$. propinquus.

\section{MATERIAL AND METHODS}

Investigations were carried out in a chestnut area near Viterbo, in the Lazio Region (Italy). The main chestnut variety in the experimental area is "Castagna" (96\%) .

Adults of $C$. propinquus were collected immediately after emergence from the soil and during feeding and egg laying activities on the trees. Larvae of C. propinquus were also captured from infested fruits after the harvest.

Four pyramid traps, $1 \mathrm{~m}^{2}$ base, were used to capture the adults flying from the soil at the base of infested trees. Chestnut branches of eight trees were shaken in the early morning and weevils were collected on a sheet placed under the canopy. Fifteen weevils which had been artificially inoculated were used as positive control. Mature larvae were collected from chestnut fruits. 
DNA was extracted from adults and larvae of weevils according to Censis (1992). Presence of Ciboria batschiana was assessed in the weevils according to Vettraino et al. (2005).

\section{RESULTS AND DISCUSSION}

A total of 32 weevils, 22 from branches and 10 from the soil, and 90 larvae, distributed in 6 groups of 15 larvae each, were tested for the presence of $C$. batschiana by means of nested PCR using the RAC1 and RAC2 specific primers (Vettraino et al., 2005). The percentage of infestations is reported in Table 1. C. batschiana was found in association with $95.4 \%$ of the adults captured from the trees, compared to $20 \%$ of the adults captured from the soil. These results confirm $C$. propinquus as a carrier of the fungus, although no evidence of the role as vector can be stated at the moment. The higher frequency of $C$. batschiana on insects feeding on the crown compared to those flying from the soil, would suggest that $C$. propinquus is contaminated mainly during its feeding activity. No information is available at the moment on the localization of the fungus on the insect. Both male and female insects were found to be associated with $C$. batschiana. This would suggest that adults can be contaminated not only by egg-laying activities on fruits, but also during feeding on other tissues and organs (e.g. leaves, buds and stems). Only $33.3 \%$ of the larvae DNA yielded the expected fragments of $296 \mathrm{bp}$ following nested PCR. Additional investigations are needed in order to determine the role of $C$. propinquus as a vector of the black rot fungus $C$. batschiana. In particular, the source of contamination and the localization of the inoculum on (or into) the insect deserve specific studies.

\section{Literature Cited}

Cenis, J.L. 1992. Rapid extraction of fungal DNA for PCR amplification. Nucleic Acids Research 20:2380.

Delatour, C. and Morelet, M. 1979. La pourriture noire des glands. Biologie et Forêt XXXI-2:101-115.

Feci, E., Smith, D. and Stanosz, G.R. 2003. Association of Sphaeropsis sapinea with insect-damaged red pine shoots and cones. Forest Pathol. 33:7-13

Finch-Savage, W.E., Clay, H.A., Budge, S.P., Dent, K.C., Clarkson, J.P. and Whipps, J.M. 2003. Biological control of Sclerotinia pseudotuberosa and other fungi during moist storage of Quercus robur seeds. Eur. J. Plant Pathol. 109:615-624.

Müllera, M.M., Varamaa, M., Heinonenb, J. and Hallakselaa, A.M. 2002. Influence of insects on the diversity of fungi in decaying spruce wood in managed and natural forests. Forest Ecol. Manag. 166:165-181.

Paparatti, B., Speranza, S., Terrosi, A. and Pucci, C. 2002. Prova di campionamento degli adulti di balanino del castagno (Curculio propinquus Desbr.) per mezzo di trappole cromotropiche e chemio-tropiche. Proc. XIX Congresso Nazionale di Entomologia, Catania, 10-15 Giugno 2002. p.917-920.

Peyronel, B. 1920. La forma ascofora della Rachodiella castaneae agente del Nerume delle castagne. R. C. Accademia dei Lincei, ser.V vol XXIX:324-327.

Speranza, S. 1999. Chestnut pests in Central Italy. Acta Hort. 494:417-423.

Tian, S.P. and Bertolini, P. 1997. Biology and pathogenicity of Rachodiella castaneae in chestnuts stored at low temperatures. J. Plant Disease and Protection 104:23-28.

Vettraino, A.M., Paolocci, A.R and Vannini, A. 2005. Endophytism of Sclerotinia pseudotuberosa: PCR assay for specific detection in chestnut tissues. Mycological Research 109:96-102. 


\section{$\underline{\text { Tables }}$}

Table 1. Occurrence of S. pseudotuberosa in adults and larvae of C. propinquus collected from trees, soil and nuts in a chestnut area in Central Italy.

\begin{tabular}{cccccc}
\hline Sample origin & $\begin{array}{c}\text { insects collected } \\
\left(\mathrm{n}^{\circ}\right)\end{array}$ & \multicolumn{2}{c}{$\begin{array}{c}\text { insects contaminated } \\
\left(\mathrm{n}^{\circ}\right)\end{array}$} & $\begin{array}{c}\text { percentage of } \\
\text { contamination (\%) }\end{array}$ \\
\hline & male & female & male & female \\
Soil & 5 & 5 & 1 & 1 & 20.0 \\
Tree & 9 & 13 & 8 & 13 & 95.4 \\
\hline Total & 14 & 18 & 9 & 14 & 71.9 \\
\hline Larvae (bulk) & 6 & 6 & 2 & & 33.3 \\
\hline
\end{tabular}

\section{Figures}

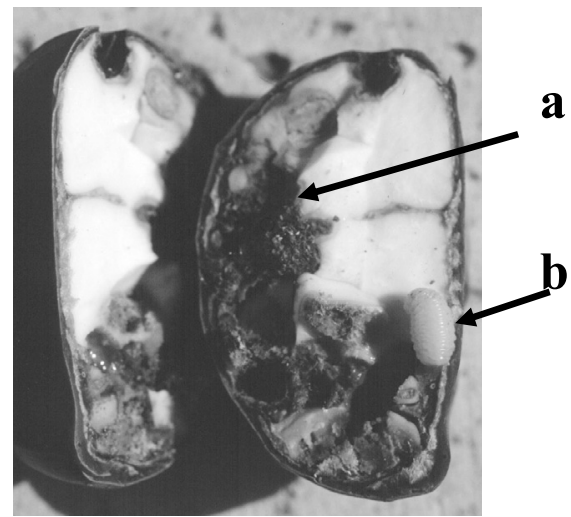

Fig. 1. Occurrence of black rot caused by S. pseudotuberosa (a) and a larva of $C$. propinquus (b), in a chestnut nut. 
